\title{
O ESTRUTURALISMO EM JACQUES LACAN: DA APROPRIAÇÃO À SUBVERSÃO DA CORRENTE ESTRUTURALISTA NO ESTABELECIMENTO DE UMA TEORIA DO SUJEITO DO INCONSCIENTE
}

Luis Flávio Silva Couto e Marcelo Fonseca Gomes de Souza

Luis Flávio Silva Couto Psicanalista, doutor em Filosofia pela Universidade Federal do Rio de Janeiro, pósdoutorado em psicanálise pela Universidade Paris VIII, professor adjunto da PUCMG, professor associado aposentado pela UFMG.

Marcelo Fonseca Gomes de Souza

Psicólogo, doutorando em Psicanálise pela FafichUFMG, mestre em Psicanálise pela FafichUFMG, professor da Faculdade Divinópolis (Faced).
RESUMO: Pretende-se situar a psicanálise lacaniana em relação ao estruturalismo. Para isso, os autores descrevem tanto a apropriação feita por Lacan dos conceitos derivados do estruturalismo linguístico e antropológico quanto o movimento de subversão produzido por ele. O sujeito do inconsciente é o operador nuclear que permite apontar o estatuto particular da corrente estrutural no pensamento de Lacan, diferenciando-o do estruturalismo filiado às propriedades da ciência moderna. Se a estrutura da linguagem, num certo momento do ensino desse autor, é o campo epistêmico que define a especificidade do dispositivo psicanalítico, essa estrutura, no entanto, situa, numa posição de inclusão-externa, um ser que lhe é estranho: o sujeito.

Palavras-chave: Estruturalismo, psicanálise, linguagem, sujeito do inconsciente, ciência moderna.

ABSTRACT: The structuralism in Jacques Lacan: from the appropriation to the subversion movement in establishing a theory of the subject of the unconscious. This article intends to situate the Lacanian psychoanalysis in relation to structuralism. The authors describe the appropriation made by Lacan of the derivative concepts from linguistic and anthropologic structuralism and also the subversion movement produced by him. The subject of the unconscious is the nuclear operator that allows the evaluation of the particular statute from the structural line of Lacan's thought. If the language structure, in a given moment of this author`s theory, is the epistemic area that defines the specificity of the psychoanalytical device, this structure, however, places in a position of external inclusion, a strange existence: the subject.

Keywords: Structuralism, psychoanalysis, language, subject of the unconscious, modern science. 


\section{CONSIDERAÇÕES INTRODUTÓRIAS}

Para avaliarmos o estatuto do estruturalismo de Jacques Lacan, é importante ter em mente que os movimentos de apropriação e subversão da corrente estrutural que trataremos de descrever estão, na obra desse autor, diretamente relacionados ao campo específico de sua abrangência. É preciso sublinhar, de antemão, que é a partir da práxis psicanalítica, dos seus núcleos de referência, que iremos pensar as formulações importadas de domínios do saber que lhes são estrangeiros. Ainda que seja necessário um retorno às fontes que inspiraram a obra lacaniana num momento importante de seu ensino, não será por uma fidelidade irrestrita a essas fontes que tal retorno será promovido. Se a linguística e a antropologia estruturais são operadores privilegiados para estabelecer, com rigor conceitual, o vasto terreno de apresentação dos fenômenos inconscientes, elas, no entanto, não interessam por si mesmas, e, por conseguinte, não ficam em posição de legislar sobre os caminhos assumidos pela psicanálise, uma vez que esta possui um domínio de validade que lhe é próprio. (LACAN, 1970/2003)

Lacan sugere que a peculiaridade de um campo implica operações específicas intrínsecas ao seu escopo de investigação. Mesmo que algumas ferramentas trazidas de outras áreas possibilitem à psicanálise expandir seu horizonte de inteligibilidade, isso não significa, todavia, que uma apropriação deva ser reportada escrupulosamente às suas fontes. O termo apropriação denota, pelo contrário, a ação de tornar próprio, isto é, fazer com que os conceitos funcionem dentro de um sistema dessemelhante àquele de onde eles surgiram originariamente. A concepção de Lacan é, nesse sentido, radical. Apesar de utilizar os conceitos provenientes da linguística estrutural, por um movimento retroativo, ele os faz retornar de modo diferente para o campo de onde nasceram. Assim, se num momento a articulação do pensamento inconsciente feita pela psicanálise deve sua formulação mais clara à linguística, no instante seguinte, pelas consequências produzidas por seu exame, Lacan é levado à afirmação oposta: a de que o inconsciente, pensado através dos meios disponibilizados pela linguística, pode ter sido a condição para o surgimento desta. Como ele mesmo trata de apontar: "A linguística fornece o material da análise, ou o aparelho com que nela se opera. Mas um campo só é dominado por sua operação. O inconsciente pode ser, como disse, a condição da linguística. Esta, no entanto, não tem sobre ele a menor influência." (LACAN, 1970/2003, p.407)

Essa complexa forma de teorização, que permeia todo o texto lacaniano, permite-nos situar, antecipadamente, o plano que seguiremos: reportar as referências advindas do estruturalismo apenas ao universo de nossas ocupações - o momento do ensino de Lacan no qual o Simbólico se apresenta como eixo privilegiado. 
Para estabelecer, de maneira um pouco mais precisa, o âmbito de referência da psicanálise — que fará com que a "máquina” estruturalista seja posta em ação - , é necessário situar seu ponto de baliza. Este, podemos dizer sem o perigo do equívoco, é o sujeito. Mais especificamente, o sujeito do inconsciente $(\$)$. Para Lacan, é justamente esta a função da estrutura: ela atua "não como modelo teórico, mas como a máquina original que nela põe em cena o sujeito”. (LACAN, 1960/1998a, p.655)

Ao colocar o sujeito em cena, ao iluminar o espaço constrito onde ele surge para logo se despedir, não estaria Lacan, portanto, bem distante do ideal que guia a filiação da linguística e da antropologia estruturais à ciência moderna? À incompatibilidade existente entre o estruturalismo e uma teoria do sujeito, Lacan responde de modo subversivo, fazendo da estrutura o 'topos' privilegiado para pensar o sujeito como categoria indispensável à sua prática. A psicanálise recupera o dejeto das operações da ciência — seu sujeito — e dele faz o núcleo de suas ocupações.

Apesar de o sujeito ser o pivô de uma práxis - e de uma teoria que a reflete e retroalimenta o campo da ação analítica —-, seria falacioso afirmar que ele é anterior à estrutura. É, pelo contrário, por haver uma estrutura sociolinguística preliminar à existência de um indivíduo qualquer que o sujeito pode advir enquanto tal. Dessa forma, o sujeito não é desde sempre. Ele não possui qualidades a priori que determinam, previamente, o campo de suas experiências. Ele, antes, é agido, isto é, determinado pelos efeitos da estrutura que preexistem à sua relação com o mundo. "O efeito de linguagem é a causa introduzida no sujeito. Por esse efeito, ele não é causa dele mesmo, mas traz em si o germe da causa que o cinde. Pois sua causa é o significante sem o qual não haveria nenhum sujeito no real." (LACAN, 1966/1998, p.849)

A máquina estrutural, portanto, é aquela que põe o sujeito em cena. Ela está lá e somente a partir dela um sujeito pode ser instituído.

Mas, desaceleremos a marcha. Muitos elementos foram colocados nesta introdução sem, contudo, receberem a atenção merecida. Retornemos a eles, para que os passos não sejam trôpegos e não concluamos apressadamente, sem esclarecer os procedimentos empregados no processo de nossa análise. Assim, ao planejar cuidadosamente a jornada, talvez alguns percalços possam ser evitados.

É imperioso que algumas definições sejam estabelecidas. Para tanto, o caminho empreendido será o seguinte: 1) especificaremos em que o estruturalismo importa para a psicanálise; em seguida, 2) delimitaremos o conceito de estrutura, bem como de sua teoria: o estruturalismo; e, por fim, 3) colocaremos a questão referente à noção de sujeito do inconsciente (\$) e sua relação com a estrutura. 


\section{O ESTRUTURALISMO E A PSICANÁLISE}

Quais são as condições de possibilidade da psicanálise? "A psicanálise” — afirma Miller — “só é possível se, e somente se, o inconsciente for estruturado como linguagem. O que se chamou o ensino de Lacan é o desenvolvimento desta hipótese até suas últimas consequências”. (MILLER, 1988, p.12)

O inconsciente é estruturado como uma linguagem. O que podemos extrair disso? De um modo bem rudimentar, para não dizer trivial, podemos considerar que entre as formas de apresentação do inconsciente, desde as formulações de Freud, e a estrutura interna de organização da linguagem, as semelhanças são inequívocas. Basta determo-nos com alguma atenção na obra freudiana, para constatar que a linguagem atua como ponto basal para os processos de operação na clínica. Os sintomas, os sonhos, os atos falhos, os esquecimentos, os chistes, etc., falam. Mais ainda: esses fenômenos se pronunciam de um lugar onde a consciência de um sujeito não só é incapaz de se reconhecer enquanto vinculadora da mensagem anunciada, como se esforça para que essa mensagem não seja reconhecida. O inconsciente apresenta-se cifrado e disjunto de uma razão plenamente consciente dos seus processos intelectivos.

Se o inconsciente mantém uma relação íntima com a linguagem, é necessário pressupor que o seu modo de funcionamento não seja errático. Apesar da isenção de contradição mútua, da intemporalidade e da substituição da realidade externa pela psíquica (FREUD, 1915/1996, p.192), propriedades que o distinguem da consciência, o sistema inconsciente apresenta algumas regularidades. Freud demonstra que essa instância psíquica apresenta-se por meio de dois mecanismos básicos: a condensação e o deslocamento. "Pelo processo de deslocamento uma ideia pode ceder à outra toda a sua cota de catexia; pelo processo de condensação pode apropriar-se de toda catexia de várias outras ideias.(...) esses dois processos [são] considerados como marcos distintivos do assim denominado processo psíquico primário.” (FREUD, 1915/1996, p.191)

Mesmo que haja uma grande distância em relação aos minuciosos esquemas de organização de que dispõe o sistema da consciência (esquemas que permitem crivar, classificar e hierarquizar a realidade), alguma ordem é pressuposta no inconsciente. Para que a psicanálise tenha adquirido a sua condição de possibilidade no universo do saber moderno, Freud precisou postular que o inconsciente possui leis operatórias próprias.

Um parêntese para facilitar o entendimento. A organização de uma ciência, como a psicanálise, não prescinde de um conjunto de hipóteses preliminares que circunscrevam seu campo de ação. Tais hipóteses tanto revelam uma trama conceitual anterior às observações do pesquisador sobre o espaço de sua investigação, quanto calibram as técnicas que estabelecerão a maneira apropriada de 
intervenção sobre o conjunto dos fenômenos delimitados. Kant, na sua Crítica da razão pura, demarca o método subjacente às operações inerentes à razão científica:

“A razão tem que ir à natureza tendo numa das mãos os princípios unicamente segundo os quais fenômenos concordantes entre si podem valer como leis, e na outra o experimento que ela imaginou segundo aqueles princípios, na verdade para ser instruída pela natureza não na qualidade de um aluno que deixa ditar tudo o que o professor quer, mas na de um juiz nomeado que obriga as testemunhas a responder às perguntas que lhes propõe.” (KANT, 1787/1999, p.38)

Para um observador atento, a realidade conta. Porém, o pesquisador não vai a ela sem algumas pressuposições. Ao colocarmo-nos um problema qualquer, as hipóteses primárias construídas já contêm, ainda que em alguns casos em estado incipiente, o horizonte das respostas buscadas. Para um bom investigador, a prova de realidade deve ser o juiz que assevera o acerto ou o equívoco das hipóteses produzidas. Caso a hipótese se revele insuficiente, a teoria é refutada e, ulteriormente, um novo conjunto explicativo é formulado para que uma solução correta advenha.

Freud, guiado pelo ideal da ciência de sua época, emprega o método descrito. Nesse sentido, a hipótese de que os mecanismos de condensação e deslocamento do material ideativo representam o dialeto pelo qual o inconsciente se expressa determina as formas assumidas pela técnica psicanalítica. A práxis da psicanálise é coextensiva às pressuposições estabelecidas. Afinal, não há técnica que possa ser compreendida e corretamente aplicada "quando se desconhecem os conceitos que a fundamentam” (LACAN, 1953/1998, p.247). Pela descrição e formalização desses mecanismos — bem como de seus registros tópicos, de seus processos dinâmicos e da economia de sua energética —- Freud constituirá grande parte de seu arcabouço metapsicológico.

'Fale tudo o que vier à cabeça!'. A associação livre, expressa por esse imperativo, é a lei principal e a única regra do dispositivo analítico. Tal lei é promulgada e constitui a base de uma experiência porque está sustentada na concepção de que, ao se entregar a uma fala desgovernada, o paciente não dirá qualquer coisa. O aparente absurdo do encadeamento de imagens em um sonho, os tropeços e equívocos da fala num momento do discurso, a evocação de lembranças que não guardam nenhuma relação com o conteúdo do que estava sendo dito, mas que, num instante preciso, irrompem no pensamento do analisante, são alguns exemplos de fenômenos que Freud avalia. A partir de uma consideração preliminar sobre a ordem de aparecimento desses eventos, Freud é claro ao considerar que existe uma causalidade que os determina. 
O 'Fale tudo' aponta, consequentemente, que todo o dito e todo o não dito pelo paciente no curso de sua análise são relevantes. A importância conferida a tudo o que se diz num 'setting' clínico, bem como a tudo o que é silenciado, deve ser acompanhada, para um cientista, da seguinte formulação: 'Tudo o que você disser tem uma causa'. Estamos no ponto paroxístico da razão, que busca, nos efeitos da fala - quaisquer que sejam eles e por mais estranhos e desarticulados que sejam suas formas de aparecimento - , as leis que estruturam as causas subjacentes ao pensamento inconsciente.

O trajeto que realizamos até aqui possui um único objetivo: situar, segundo Lacan, o campo de referência da psicanálise. A demarcação dos mecanismos eleitos por Freud para falar dos modos de funcionamento do processo primário, a consideração de que as diversas formações do inconsciente portam significações que transcendem o seu sentido manifesto, a concepção de que existem causas ocultas, subjacentes a esses fenômenos corriqueiros aos quais o eu ('moi') insiste em prestar pouca atenção, tudo isso revela, para Lacan, na sua proposta de um retorno a Freud, que os conceitos freudianos só podem adquirir pleno sentido por estarem dispostos num campo específico - o da linguagem - e por "se ordenarem na função da fala”. (LACAN, 1953/1998, p.247)

O inconsciente opera segundo uma lógica determinada. Por ser estruturado como uma linguagem, sua lógica deve ser delimitada pelos mecanismos intrínsecos ao funcionamento desta. Ora, é por meio do estruturalismo linguístico e antropológico que Lacan buscará elucidar tais mecanismos.

Como reforça Miller, a imersão no estruturalismo é uma tentativa lacaniana de

“formalizar a estrutura que sustenta a fenomenologia da experiência analítica. É, evidentemente, uma estrutura complexa, pois os fenômenos que ocorrem na experiência analítica dão, à primeira vista, a impressão de que não podem estar estruturados, mas a metáfora [condensação] pode ser estruturada, a metonímia [deslocamento] pode estar estruturada, o equívoco pode estar estruturado, a função do Outro na delimitação do sentido pode estar estruturada.” (MILLER, 1988, p.44)

Por ser um terreno tão fértil para a formalização da psicanálise lacaniana, é preciso, portanto, conhecer o estruturalismo com um pouco mais de profundidade. É necessário avaliar o que, de fato, define a linguagem, quais são as suas propriedades e como ela funciona, pois, assim procedendo, podemos também entender melhor o que quer dizer isto: o inconsciente. 


\section{A ESTRUTURA DOS ESTRUTURALISTAS}

"Em que se reconhecem aqueles que chamamos de estruturalistas?" (DELEUZE, 1974, p.271). Vejamos o que Lacan nos indica com respeito a essa indagação: “Todo fenômeno analítico, todo fenômeno que participa do campo analítico, da descoberta analítica, daquilo que lidamos no sintoma e na neurose, é estruturado como linguagem. Isto quer dizer que é um fenômeno que apresenta sempre a duplicidade essencial do significante e do significado." (LACAN, 1955-56/2008, p.196)

A citação evoca rapidamente, sem quaisquer rodeios, a partir do exemplo da linguística, o lugar e os elementos que circunscrevem o que está em causa para os estruturalistas. Ao falar de estrutura, é elucidativo nos reportarmos à linguagem (DELEUZE, 1974, p.271). Mais especificamente, à maneira como a linguística estrutural — derivada de Saussure, mas também da escola de Praga - dela se apropria para constituí-la como objeto de interesse científico. Em relação aos elementos mínimos que a compõem, cabe também destacá-los do trecho acima, são eles o significante e o significado.

Na linguística, a estrutura é definida pelos constituintes elementares que operam na linguagem e que determinam seu sistema de funcionamento. Ainda que as línguas assumam formas expressivas distintas, proporcionem aos interlocutores uma ampla gama de efeitos e possibilitem inúmeras formas de interações comunicacionais, isto é, ainda que possamos ligar à linguagem uma extensa quantidade de fenômenos, é possível determinar os elementos mínimos e universais que, atuando autonomamente, configuram essas diversas modalidades de manifestação. À linguística, afirma Iannini,

“caberá um papel fundamental: fornecer o paradigma de como orquestrar a multiplicidade aparente da empiria na unidade da estrutura. Como nos atesta o próprio Lévi-Strauss ao prefaciar uma obra de Jakobson: a linguística estrutural ensina que 'em vez de nos deixarmos perder pela multiplicidade dos termos, é preciso considerarmos as relações mais simples e mais inteligíveis que os unem’.” (1998, p.67)

Dessa forma, ao excesso de sentido que a língua suporta, à sua variedade fenomênica, à sua pluralidade performativa, os linguistas estruturais respondem com o isolamento de elementos mínimos que operam por um número definido de relações constantes.

É exatamente essa operação que caracteriza a formalização do estruturalismo. A estrutura é uma redução da linguagem aos seus suportes essenciais, de forma tal que ao objeto tomado em consideração — seja ele proveniente da literatura (sua estrutura compositiva), da filosofia (seu alicerce epistêmico), da história (sua démarche), da antropologia (o mito ou as estruturas de parentesco), da psicanálise 
(o inconsciente), etc. — corresponda uma definição rigorosa e simplificada. Elencar essas diversas disciplinas, aplicando a elas uma mesma adjetivação, embora haja enormes distinções quanto aos fenômenos aos quais elas se apõem, consiste essencialmente nisto: tratar seus objetos - em geral agrupados nas ditas ciências conjecturais - como pertinentes ao campo da linguagem. Podemos, então, afirmar sinteticamente que o "nome do sistema reduzido à sua relação mínima é estrutura; o nome estruturalismo designa sua teoria”. (MILNER, 1996, p.80)

Ora, a Linguística estrutural, pela especificidade de seus procedimentos, emancipa-se dos estudos anteriores sobre a linguagem justamente por tomá-la como um objeto passível de investigação científica. Se isso acontece com ela, bem como com todas as disciplinas estruturalistas, o movimento de filiação à ciência, mesmo que este se revele apenas como um ideal, é uma marca importante a ser destacada. Entretanto, o que isso sugere? O que falamos quando dizemos a ciência?

Isso sugere que foi preciso definir a linguagem de maneira distinta das acepções que até então haviam prevalecido. Os pré-socráticos deram origem a uma tradição de pensamento sobre a linguagem que a considerava como parte integrante da 'physis', formando com esta uma unidade. Para eles, as palavras representavam indubitavelmente as coisas que elas por natureza nasceram para designar. Não havia aí nenhuma fissura entre umas e outras, mas, sim, uma relação de estrita complementaridade. (GARCIA-ROZA, 1998)

Essa relação entre palavras e coisas é tema do Crátilo, famoso diálogo de Platão que discorre sobre a linguagem. Nele, se pudermos resumi-lo de forma bem condensada, Sócrates debate com Hermógenes e Crátilo a relação existente entre as palavras e as coisas. O primeiro interlocutor defende a ideia do caráter convencional da linguagem, ou seja, que a relação da palavra à coisa é estabelecida pelo hábito e pela tradição. O segundo propõe a relação de conaturalidade, isto é, de adequação das palavras às coisas que elas nasceram para nomear. Sócrates intervém aí e, através de um longo percurso, demonstra tanto a precisão quanto a inexatidão que as duas concepções oferecem. O caráter aporético do Diálogo revela justamente a ausência de uma resposta decisiva sobre o estatuto do nome ('onoma'). Como Sócrates demonstra para Crátilo, o nome, caso bem construído, é semelhante à coisa. Todavia, se ele fosse perfeitamente adequado a ela, ele a reproduziria com perfeita simetria, tornando-se, desse modo, a própria coisa designada. Portanto, por ter composição distinta da coisa reproduzida, é preciso que alguma convenção lhe seja pressuposta.

“Eu também defendo o princípio de que os nomes devem assemelhar-se o quanto possível à coisa representada; porém, receio muito que, de fato, como disse há pouco Hermógenes, seja bastante precária a tal força de atração de semelhança e 
que nos vejamos forçados a recorrer a esse expediente banal, a convenção, para a correta imposição dos nomes.” (PLATÃO, 2001, 435 c-d)

A resolução dessa dificuldade será apresentada no final do Diálogo, ainda que a forma de sua produção careça de demonstração. Ao radicalizar seus passos argumentativos, Sócrates acaba por encontrar uma saída efetiva. Dada a impossibilidade de se conhecer o nome do nome, é preciso procurar a verdade das coisas não por intermédio de suas imagens, mas através do acesso à sua própria essência. O mestre-filósofo, contudo, não nos revela como essa tarefa será empreendida. "O modo de alcançar o conhecimento das coisas, ou de descobri-las, é questão que talvez ultrapasse a minha e a tua capacidade. Basta-nos termos chegado à conclusão de que não é por meio de seus nomes que devemos procurar conhecer ou estudar as coisas, mas, de preferência, por meio delas próprias." (PLATÃO, 2001, p.439 b)

Aristóteles tenta responder o problema levantado por Platão. A sua filosofia, contudo, caminha de um modo distinto da de seu mestre. É pela imanência das coisas no mundo, e não pela transcendência de uma Ideia genética, que ele faz entrar a palavra. As palavras, nesse sentido, não manifestam as coisas, apenas as significam. Não as imitam ou copiam, mas as denotam. Todavia, se o vínculo que une a palavra ao ser é rompido, como é possível estabelecer uma verdade filosófica?

Para não cair no perigo da sofística, Aristóteles distingue o discurso corrente do discurso proposicional. A proposição é o lugar privilegiado no qual o discurso sai de si para captar as coisas mesmas em sua vinculação recíproca. O que determina a verdade de um discurso é o próprio conjunto de regras inerentes à lógica proposicional. Em oposição à dialética, ou num desenvolvimento desta, Aristóteles constrói a lógica como método de alcançar o conhecimento das coisas.

Dessa forma, a prova de um bom discurso não é revelada pelos efeitos que ele produz em um interlocutor ou em uma plateia. O bom discurso, o discurso verdadeiro ('orthologos'), é aquele que expressa corretamente o seu vínculo com o ser das coisas.

O discurso, portanto, é capaz, caso se empregue o método correto, de manter uma relação com a essência que ele busca apreender. Aristóteles também pressupõe, na sua teoria da linguagem, uma ontologia. Garcia-Roza, precisando o texto aristotélico, pontua: “Se a linguagem e o pensamento são possíveis é porque as palavras possuem um sentido definido, e as palavras só possuem um sentido definido porque as coisas possuem uma essência.” (GARCIA-ROZA, 1998, p.74)

Essa relação existente entre as palavras e as coisas, pensada pela filosofia clássica, é radicalmente disjunta da operação implementada pela linguística 
estrutural. Para que a língua seja tomada como objeto da ciência, o cientista precisa romper a vinculação pressuposta entre palavras e coisas. As perguntas sobre a gênese da linguagem, a sua pertinência à natureza que ela representa, ou ainda tantas outras inquirições que objetivam percorrer o complexo universo que a atrela a uma ontologia, devem ser abandonadas. O que deve surgir em seu lugar é a possibilidade de tomar a língua como uma entidade autônoma, desvinculada da realidade que ela nomeia. A língua passa, então, a ser estudada como um fenômeno independente que possui, intrinsecamente, um conjunto de relações que ordenam e estruturam as formas de seu aparecimento. Como afirma Ribeiro:

“Saussure efetua um passo no qual é possível de se notar um ato de rompimento radical com a perene ideia de que a língua, em seu funcionamento, porta o estatuto de uma nomenclatura. Em outras palavras, podemos testemunhar Saussure se desligando, em suas elaborações, da ideia de que a língua funciona basicamente aos moldes da ostensão." (2001, p.125)

Desse modo, a realidade, para a linguística estrutural, perde a sua primazia e passa, por uma inversão radical, a ser compreendida não mais como causa, mas, agora, como efeito do funcionamento dos processos da linguagem. Os signos tornam-se, dessa maneira, mais reais do que aquilo que eles significam.

Lacan demonstra com um exemplo a função elucidativa ocupada pela metáfora para apontar essa independência da linguagem em relação à realidade. Trata-se de uma indicação clara de que o ser e as palavras não estão vinculados numa ordem hierárquica natural. Indica, pelo contrário, que a linguagem possui um poder próprio de abstração mediante a anulação da facticidade do referente.

“É a metáfora como aquilo em que se constitui a atribuição primária, aquela que promulga o "o cachorro faz miau o gato faz au-au" com que a criança, de um só golpe, desvinculando a coisa de seu grito, eleva o signo à função do significante e eleva a realidade à sofística da significação, e, através do desprezo pela verossimilhança, descortina a diversidade das objetivações a serem verificadas de uma mesma coisa." (LACAN, 1960/1998b, p.820)

Para a linguística, a única vinculação que resta entre palavras e coisas é colocada na ordem do arbitrário.

Entendido esse desacoplamento realizado pela linguística estrutural, é preciso, agora, retornar à questão suscitada um pouco acima: o que sugere a pertinência dessa disciplina ao universo da ciência moderna? O que significa, em outras palavras, fundar a linguística como ciência? 
Sem dúvida, para que a linguística esteja contida no conjunto ciência moderna, é imperativo que ela possua as propriedades desse conjunto. Mas, quais são essas propriedades?

\section{A CIÊNCIA MODERNA}

Pode-se dizer que a ciência moderna é debitária da física de Galileu (MILNER, 1996). Para Koyré, a característica mais saliente que define a especificidade da ciência galileana é a novidade produzida por seu método. Neste,

“a teoria matemática determina a própria estrutura da pesquisa experimental ou, para retomar os próprios termos de Galileu, um método que utiliza a linguagem matemática para formular suas indagações à natureza e para interpretar as respostas que ela dá. Um método que, substituindo o mundo do mais ou menos conhecido empiricamente pelo Universo racional da precisão, adota a mensuração como princípio experimental mais importante e fundamental." (KOYRÉ, 1956/1982, p.74)

O abusivo sistema de relações que buscava explicar a ordenação e o destino das coisas encontradas na realidade; a clivagem do mundo empírico em um sistema de hierarquias que dispunham os seres em classes determinadas (do mais necessário e perfeito até o mais contingente e precário); a proliferação de sentidos, consequência das sucessivas tentativas de relacionar fenômenos incomunicáveis numa teoria única e generalizada, todas essas são características próprias do saber antigo. É justamente dessa forma de conhecimento que a ciência moderna afasta-se de modo radical. O corte que ela introduz visa, exatamente, a retirar do mundo o excesso imaginário da significação. Para possibilitar tal corte, foi necessário o rompimento da relação de adequação e complementaridade entre o sujeito e o objeto e, no mesmo movimento, a adoção da matematização como a linguagem operativa própria à ciência.

A ciência moderna, escreve Teixeira, “(...) extingue radicalmente, do dispositivo simbólico, a exigência imaginária da significação, na medida em que estabelece fórmulas que funcionam como uma espécie de sintaxe do real, sem se ocupar, no entanto, com o conteúdo que essas fórmulas significam”. (2007, p.140)

A física matematizada elimina todas as qualidades dos existentes. O universo composto pelas imagens, pelas analogias e pelos intermináveis sentidos atribuídos aos seres decai e, em seu lugar, arquiteta-se uma forma de operação capaz de tratar o real pela exatidão asséptica do simbólico. A língua dos cálculos, para tanto, pretende ser precisa e universal. 
Ao dizer que Saussure funda a linguística como ciência, é, pois, preciso considerar que ele constitui um objeto autônomo e que o escreve em caracteres matemáticos. Para que o estruturalismo seja, portanto, uma figura da ciência moderna, deve aplicar ao seu objeto um procedimento semelhante ao empregado pela física, resguardadas, é claro, as devidas diferenças entre seus campos: uma pertencente ao domínio da natureza; o outro, ao domínio da cultura.

Ao reclamar para si o ideal da ciência, foi preciso que o estruturalismo ampliasse, para um objeto humano, as noções anteriormente aplicadas apenas ao domínio da 'physis'. A extensão para outros objetos implicou, também, um alargamento das estratégias metódicas de matematização até então utilizadas. O ideal da precisão foi mantido a partir de uma calibragem nas formas de seu emprego: já “não se trata mais da medida, 'stricto senso', mas de uma literalização e de uma dissolução não quantitativa do qualitativo” (MILNER, 1996, p.75). A manutenção das qualidades nas ciências conjecturais não implicou, contudo, perda da supremacia da matemática. Ao contrário, o método da matematização aumentou o seu reinado ao se fazer ainda mais rigoroso. Para dar conta dos ditos fenômenos humanos, ele precisou ser impulsionado em direção a um literalismo absoluto.

A linguística, ao matematizar seu objeto, pôde, então, equacioná-lo dentro de um conjunto simplificado de relações. Desse modo, tornou-se possível captar e explicar as distâncias, as proporções e as simetrias dos constituintes elementares que operam no interior do sistema: os signos. O signo linguístico é a unidade mínima, primitiva e evidente que sustenta o sistema (MILNER, 1987). Pela delimitação de suas propriedades, torna-se possível explicar o modo de funcionamento da língua. Estas podem ser descritas do seguinte modo:

“o signo linguístico é arbitrário” (SAUSSURE, 1979, p.136). O vocábulo utilizado para significar uma coisa não guarda, com essa coisa, uma relação de pertinência. O que o leva a designá-la, bem como a fixar e estabilizar um sentido, poderia, num contexto e num momento diferentes, assumir uma feição bastante distinta daquela que foi, convencionalmente, adotada e propagada;

os signos dispõem-se numa extensão, isto é, apresentam-se um após o outro, formando, assim, uma linha ou cadeia. Tal característica é importante visto que é somente por existir a cadeia que, ao signo, pode ser atribuído algum valor;

a partir da propriedade 'b’, uma constatação: o signo é opositivo e relativo. Sua identidade é formada pelo processo de diferenciação que ele mantém, numa linha, com outro componente. Ele, isolado, não é nada. O valor atribuído ao signo é marcado apenas pela posição diferencial que ocupa, na cadeia, em relação a outro(s) signo(s);

a disposição dos signos em cadeias dará origem a um conjunto de relações e arranjos regulares. A isso chamamos sistema. 
As propriedades descritas, bem como todo arranjo explicativo preliminar, encaminham-nos às seguintes considerações:

1) O sistema linguístico, pela configuração própria de seus elementos, está, também, assentado no critério diferencial. Na língua só existem diferenças.

2) Existe uma regularidade própria ao sistema. A regularidade é o que importa ao linguista para o estabelecimento da sua ciência. É pelo que não cessa de se repetir na língua, que podemos estabelecer e algebrizar as leis que regem seu funcionamento. Porém, como observa Milner, fazendo uma ressalva que nada tem de trivial, a ciência, ao ater-se apenas ao que repete incessantemente, “descarta tanto o que da realidade não é necessário à repetição em seu objeto, quanto aquilo que, por si mesmo, não é repetível, (...) e, enfim, aquilo que poderia, naquilo que se repete, mascarar o que aí se repete, ou seja, as variações individuais". (MILNER, 1987, p.39)

3) Ao delimitarmos o campo da linguagem e as propriedades de funcionamento do signo, não nos referimos uma vez sequer à noção de subjetividade. Para os estruturalistas, a estrutura funciona independentemente do sujeito. $\mathrm{Na}$ verdade, a categoria sujeito é elidida da estrutura. A linguagem opera sozinha, por sua própria combinatória. Um sujeito, nesse sentido, não fala. Ele, antes, é falado pela estrutura que o antecede e o determina. Lévi-Strauss, ao pensar o mito, ilustra, de maneira extremamente clara e concisa esse movimento que também pode ser demarcado no estruturalismo antropológico:

“A análise mítica não tem, nem pode ter, por objeto mostrar como os homens pensam (...). Não pretendemos mostrar, portanto, como os homens pensam os mitos, mas como os mitos se pensam nos homens e à sua revelia. Talvez, como sugerimos, convém ir ainda mais longe, abstraindo de todo sujeito, para considerar que, de uma certa maneira, os mitos se pensam entre si.” (LÉVI-STRAUSS, 1971/1991, p.19)

Uma vez conhecidos os pilares de apoio do estruturalismo, acompanhados das considerações que propusemos acima sobre sua relação com a ciência moderna, podemos, agora, perguntar-nos sobre o estatuto dessa teoria no pensamento de Jacques Lacan.

\section{O ESTRUTURALISMO DE JACQUES LACAN}

“Lacan é estruturalista?” — pergunta Miller (1988, p.24). Segundo o autor, é possível responder a essa questão por três vias diferentes.

A primeira é uma resposta positiva. Lacan é, sim, estruturalista, pois seu conceito de estrutura provém da linguística, de Saussure e de Jakobson, por intermédio de Lévi-Strauss. 
A segunda é, também, uma reposta positiva, porém, expõe uma observação categórica. Para Miller, o estruturalismo de Lacan é radical. Seu radicalismo consiste, fundamentalmente, em fazer entrar na estrutura uma categoria zerada pelos estruturalistas. A estrutura é o operador epistêmico privilegiado pela psicanálise lacaniana, justamente porque permite pensar e situar, em posição de inclusão externa, certo existente distinto dela: o sujeito $(\$)$.

A terceira resposta é negativa. Não. Lacan não é estruturalista, pois, se para os estruturalistas, a estrutura é concebida como um conjunto coerente e completo, para Lacan ela é internamente marcada pela falta. Ao Outro falta - isso é o que Lacan designa por esse $S(\mathbb{A})$. A constatação da falta no Outro é repleta de consequências para a psicanálise.

A propósito, tomemos, como um exemplo, uma aporia arrancada da lógica. Bertrand Russel, no início do século XX, propôs e analisou o seguinte problema: como construir um catálogo que contenha todos os catálogos que não se incluem a si mesmos como verbetes? Ora, a tarefa revela-se rapidamente impraticável. Se ele se incluir na lista, o catálogo produzido não poderá ser o catálogo de todos os catálogos que não se incluem a si mesmos nos verbetes, visto que ele se inclui a si mesmo. Logo, ele precisa estar excluído. Porém, caso ele não se inclua, o catálogo também estará incompleto, visto que restará de fora ao menos um catálogo que não se inclui a si mesmo nos verbetes. A tarefa é, portanto, da ordem do impossível (FINK, 1998).

O exemplo, um entre muitos possíveis, demonstra que, mesmo para a lógica - que se livra de todo acidente subjetivo através da demonstração racional máxima - um ponto de cessação e de indecidibilidade é encontrado. Nesse lugar, o saber é suspenso. Ele falta precisamente porque a solução do problema é revelada como ausente. A figura do paradoxo surge para apontar que a estrutura da linguagem produz, internamente, sua própria impossibilidade. Um elemento permanece internamente excluído do conjunto. Esse elemento, ao mesmo tempo que dá consistência ao conjunto, impede que ele seja completo.

Ora, se optarmos por abandonar a lógica e tomarmos, agora, a língua, os exemplos se alastram. Na boca de um ser falante, ela passa por frequentes acidentes que, a todo instante, descompletam a homogeneidade e a regularidade nela pressupostas. Os imprevistos da fala interrompem, num átimo, a expectativa da significação presumida: é aí, nesse espaço do inopinado, que Lacan, atento à descoberta freudiana, põe em cena o sujeito.

A todo instante, percebemos que a língua é percorrida por falhas. A poesia, por exemplo, ao fazer da língua sua matéria, demonstra a plasticidade interna das formas da estrutura. O efeito poético está relacionado à desestabilização do sentido esperado no Outro, ou seja, ao rompimento do enfado da significação antecipadamente prometida. O chiste, da mesma forma, na comicidade que surge 
como resultado de seu proferimento, expõe, pela autorização da plateia à qual ele se dirige, que algo falta lá onde se esperava uma estrutura completa.

A partir do trajeto realizado, podemos constatar, de maneira bem sucinta, que, por detrás dos enunciados de uma fala, há um sujeito da enunciação. Mais ainda: que esse sujeito é determinado, mas não-todo, pelos efeitos da estrutura. Como Lacan demarca:

"O corte da cadeia significante é único para verificar a estrutura do sujeito como descontinuidade no real. Se a linguística nos promove o significante, ao ver nele o determinante do significado, a análise revela a verdade dessa relação, ao fazer dos furos do sentido os determinantes do seu discurso." (LACAN, 1960/1998b, p.815)

A psicanálise assume, portanto, como função nuclear, a tarefa de recuperar o sujeito elidido do discurso da ciência e, a partir do seu trabalho com a subjetividade, estabelecer-se - paradoxalmente ao recorrente ideal de universalidade da ciência — como uma ciência do particular. No dizer de Teixeira:

“A psicanálise surge antes enquanto reposta ao mal-estar gerado pela dificuldade, que experimenta o sujeito, em se adequar à unidade da classe em que ele se nomeia. Há sempre algum resto da exigência pulsional que resiste a ser integrado na unidade da representação, manifestando a cisão inerente à apresentação subjetiva nas formações do inconsciente, como se vê na irrupção dos sintomas, dos chistes, dos atos falhos." (2007, p.48-49)

Portanto, desde Freud, a psicanálise enuncia isto: “que, em matéria de língua, a ciência pode faltar" (MILNER, 1987, p.8). Sua falta se dá porque, entre um e outro significante da cadeia, um sujeito deve ser suposto: o significante, afinal, é o que representa o sujeito para outro significante. (LACAN, 1960/1998)

Sendo assim, determinada a centralidade do sujeito do inconsciente para a psicanálise, torna-se necessário responder à seguinte indagação: “Uma vez reconhecida a estrutura da linguagem no inconsciente, que tipo de sujeito podemos conceber-lhe?" (LACAN, 1960/1998, p.814). Contudo, eis aí uma questão para uma reflexão ulterior.

Recebido em 11/1/2010. Aprovado em 8/6/2010.

\section{REFERÊNCIAS}

DELEUZE, G (1974). "Em que se pode reconhecer o estruturalismo”, in CHÂTELET, F. História da filosofia: ideias, doutrinas - O séc. XX. Rio de Janeiro: Jorge Zahar.

FINK, B. (1998) O sujeito lacaniano: entre linguagem e gozo. Rio de Janeiro: Jorge Zahar. 
FREUD, S. (1996) Edição standard brasileira das obras psicológicas completas de Sigmund Freud (ESB) Rio de Janeiro: Imago.

(1900) A interpretação dos sonhos (primeira parte) v.IV, p.1-363.

(1915) O inconsciente. v.XIV, p.165-222.

GARCIA-ROZA, L. A. (1998) Palavra e verdade na filosofia antiga e na psicanálise. Rio de Janeiro: Jorge Zahar.

IANNINI, G. P. M. (1998) “Estrutura e sujeito: a máquina original de Jacques Lacan”. Dissertação de Mestrado. Departamento de Filosofia UFMG. Belo Horizonte.

KANT, I. (1781/1999) Crítica da razão pura. São Paulo: Nova Cultural (Os pensadores).

KOYRÉ, A. (1982) Estudos da história do pensamento científico. Rio de Janeiro/ Brasília: Forense Universitária / EdUnB.

LACAN, J. (1953/1998) Função e campo da fala e da linguagem em psicanálise (1953), in Escritos. Rio de Janeiro: Jorge Zahar.

(1960) Observação sobre o relatório de Daniel Lagache: “Psicanálise e estrutura da personalidade", p.653-691.

(1960) Subversão do sujeito e dialética do desejo no inconsciente freudiano, p.807-842.

(1966) Posição do inconsciente, p.843-864.

. (1970/2003) Radiofonia. Outros escritos, Rio de Janeiro: Jorge Zahar.

(1955-56/2008) O Seminário, livro 3: As psicoses. Rio de Janeiro: Jorge Zahar.

LÉVI-STRAUSS, C. (1971/1991) Mitológicas: o cru e o cozido. São Paulo: Brasiliense.

MILLER, J. A. (1988) Percurso de Lacan: uma introdução. Rio de Janeiro: Jorge Zahar.

MILNER, J.-C. (1996) A obra clara: Lacan, a ciência e a filosofia. Rio de Janeiro: Jorge Zahar.

(1987) O amor da língua. Porto Alegre: Artes Médicas.

PLATÃO (2001) Teeteto — Crátilo. Belém: Edufpa.

RIBEIRO, A. S. (2001) “A aporia do sujeito em Lacan (1953 - 1960)”. Tese de Doutorado. Departamento de Filosofia UFMG. Belo Horizonte.

SAUSSURE, F. (1979) Curso de linguística geral. São Paulo: Cultrix.

TEIXEIRA, A. M. R. (2007) A soberania do inútil e outros ensaios de psicanálise e cultura. São Paulo: Annablume.

Luis Flávio Silva Couto

luisflaviocouto@terra.com.br

Marcelo Fonseca Gomes de Souza

marcelofgsouza@gmail.com 